\author{
Ks. Henryk DYBSKI \\ (Sankt Petersburg, WSD)
}

\title{
ŻYCIE MONASTYCZNE W KONSTANTYNOPOLU W WYPOWIEDZIACH AUTORÓW IV I V WIEKU
}

Przystępując do przedstawienia życia monastycznego w Konstantynopolu, którego budowniczym był Konstantyn Wielki i od imienia którego pochodzi nazwa tego miasta) ${ }^{1}$, nalcży na początku podkreślić, iż interesowal się on tą

${ }^{1}$ Por. Socrates, HE I 16, 1-3, GCS N.F. 1, 54-55, thum. S. Kazikowski, Warszawa 1986, $108-$ 109: „Tymczasem cesarz w pogodnej radości pędził życie po zakończeniu soboru. Dopelniwszy wtedy państwowego obchodu dwudziestolecia swoich rządów natychmiast przystapil gorliwie do odbudowy i odnowienia budynków kościelnych. Dzieło to podjął zarówno we wszystkich innych miastach, jak i w mieście nazwanym jego imieniem. Rozbudował więc dawne Byzantion, otoczył je potężnymi murami i przyozdobil przeróżnymi budowlami; uczynił z niego miasto równe Rzymowi, stolicy świata, zmienił jego nazwę na Konstantynopol ( $\mathrm{t} j$. «miasto Konstantyna») i w specjalnej ustawie zapewnił mu tytuł drugiego Rzymu. Ustawa ta wyryta została na kamiennej kolumnie i wystawiona na widok publiczny w tak zwanym Strategium w pobliżu posągu, przedstawiającego cesarza na koniu. W tymże mieście wybudował dwa kościoły, jeden pod wezwaniem Pokoju, drugi zaś pod wezwaniem Apostołów. I nie tylko, jak to już wyżej powiedziałem, umacniał pozycję religii chrześcijańskiej, lecz także usuwał kult pogański"; Sozomenus, HE II 3, 1-9, SCh 306, 236-242, thum. S. Kazikowski, Warszawa 1989, 84-87: „Tymczasem cesarz, ciągle podejmując jakieś nowe dzieło, przyczynial się do wzrostu pobożności i wszędzie wznosil Bogu najprzepiękniejsze świątynie, szczególnie zaś w metropoliach jak w Nikomedii Bityńskiej i w Antiochii nad rzeką Orontes, oraz w Bizancjum, w mieście, które wybrał sobie na stolicę, równą w prawach Rzymowi współuczestniczkę jego pierwszeństwa. Ponieważ bowiem wszystko układało się po jego myśli i odniósł sukcesy zarówno w wojnach $z$ wrogiem zewnętrznym, jak i w układach pokoju, postanowił wybudować miasto noszące jego własne imię i rangą dorównujące Rzymowi. Przybywszy zatem na równinę leżącą przed Ilionem, wedle Hellespontu, nad mogilą Ajasa, gdzie podobno achajscy uczestnicy wyprawy na Troję mieli przystań i namioty, sporządził plany, jakie i jak wielkie należało wznieść miasto; i wybudował bramy na wyniosłoścj terenu, które jesz.cze i teraz widać z morza, jeśli ktos żegluje wzdłuż brzegów. Zajętemu tymi przygotowaniami ukazał się pewnej nocy sam Pan Bóg i obwieścił mu, aby poszukał innego miejsca [do budowy]; i przenióstszy go [we śnie] do Bizancjum w Tracji, naprzeciw bityńskiego Chalcedonu, polecił mu rozbudować to miasto i nadać mu nazwę od imienia Konstantyna. Cesarz, posłuszny glosowi Boga, powiększył obszar miasta nazywanego dotychczas Bizancjum i całość otoczyl potężnymi murami. A ponieważ uważal, że miejscowi obywatele liczebnie nie odpowiadają wielkości miasta, przeto pobudowawszy tu i ówdzie wzdłuż ulic olbrzymie domostwa, jako właścicieli osiedlił w nich wraz z rodzinami tych ludzi, którzy się w społeczeństwie liczą. Po części sprowadził ich ze "starszego Rzymu», po części z innych ziem państwa. Naznaczywszy odpowiednie daniny, sumy z nich uzyskane porozdzielal z przeznaczeniem 
formą życia. Świadczy o tym m.in. niezachowany (pełen życzliwości), list Konstantyna, adresowany do św. Antoniego Pustelnika ${ }^{2}$. Warto w tym miejscu dodać, że również tenże mnich, św. Antoni (ok. 250-356), korespondował z tym cesarzem (otrzymał od niego negatywną odpowiedź), występując w obronie św. Atanazego Wielkiego (ok. 295-373) ${ }^{3}$, oskarżonego na synodzie

już to na budownictwo i upiększenie miasta, już to na wyżywienie jego mieszkańców, oraz na wszystkie inne cele, związane z gospodarką miejską. Następnie, szczodrze przyozdobiwszy miasto hipodromem, wodotryskami, krużgankami i innymi tego typu budowlami, dał mu nazwę "nowego Rzymu», Konstantynopola, i ustanowił stolicą dla wszystkich, którzy zamieszkują tereny podlegające władzy rzymskiej, na północ i na poludnie, i na wschód słońca, i nad Morzem Śródziemnym. poczynając od miast naddunajskich i Epidamnu oraz innych, rozciągających się nad Morzem Jońskim, aż po Cyrenę i tamtejszych Libijczyków w okolicy przylądka pod nazwą Borejon. Jednocześnie wzniósł drugą wielką kurię, zwaną senatem, te same przyznawszy jej przywileje i [prawo uchwalania] dni modłów, do których przywykli dawniejsi Rzymianie. I kiedy tak we wszystkim starał się uczynić miasto noszące jego imię miastem równym italskiemu Rzymowi, cel swój osiągnął. Bo za łaską Bożą nowa stolica tak się rozrosła i rozwinęla, że, jak to zgodnie wszyscy stwierdzają, zarówno pod względem zaludnienia, jak i bogactwa przewyższa dawną. Za przyczynę tych osiągnięć uważam pobożność założyciela i założonego miasta, a ponadto milosierdzie i szczodrość jego mieszkańców wobec ubogich. Tak dalece bowiem potrafi to miasto zjednywać sympatię dla wiary w Chrystusa, że wielu Żydów i prawie wszyscy poganie przyjmują tam chrześcijaństwo. A poniewaź zostało stolicą akurat w tym czasie, kiedy chrześcijańska religia rozrosła się liczebnie, nie znało przeto ani pogańskich ołtarzy, ani świątyń czy ofiar, jeśli nie brać pod uwagę, że przez pewien czas próby w tym kierunku podejmowane byly potem przez cesarza Juliana i natychmiast [zresztą] wygasly. Konstantyn więc, obsypując zaszczytami to jak gdyby nowo wybudowane miasto Chrystusa, a zarazem miasto, któremu nadal swoje własne imię, ozdobił je licznymi i wielkimi świątyniami. Również i sam Bóg wspierał zapał cesarza i przez swoje objawienia dawal rękojmię, że rozsiane po mieście kościoły są święte i przynoszą zbawienie. Najbardziej stał się znany podówczas zarówno dla obcych jak i dla mieszkańców miasta - opinia co do tego jest zgodna kościół leżący na miejscu zwanym kiedyś Hestiai. Obecnie nazywa się ono Michaelion, a kto plynie z Pontu do Konstantynopola, ma je po prawej stronie, przy czym zeglarza oddziela od niego przestrzeń okolo trzydziestu pięciu stadiów, a piechura obchodzącego położoną pośrodku cieśninę - ponad siedemdziesiąt stadiów. Okolica ta otrzymala obecnie użwaną nazwę stąd, że jak lud święcie wierzy, miał się tam ukazać Michal, arcyposłaniec Boży. I ja sam także doznawszy wielkiego dobrodziejstwa zgadzam się całkowicie, że to prawda".

${ }^{2}$ Por. Apophthegmata Patrum, series alphabetica 31 (Antoni Wielki), PG 65, 85B, thum. M. Borkowska, ŹM 4, Kraków 1994, 132: „Kiedyś abba Antoni dostał list od cesarza Konstantyna wzywający go do Konstantynopola: i zastanawial się, co robić. Zapytal więc swego ucznia, abba Pawła: «Czy powinienem iść?» A on mu na to: «Jeżeli pójdziesz, będą cię nazywać Antoni; ale jeżeli nie pójdziesz, to abba Antoni»; Sozomenus, HE I 13, 1, SCh 306,168-170, Kazikowski s. 57: ,wielki ów mnich Antoni. Tego to podówczas męża, jako ozdobę pustelni egipskich, odpowiednio do sławy jego cnót uczynił cesarz Konstantyn swoim przyjacielem, zaszczycając go swym listem i polecając mu pisać o wszystkim, czego potrzebuje"; zob. M. Borkowska, w: Apoftegmaty Ojców Pustyni, ŻM 4, 132, przypis 17 do Apoftegmatu 31 .

3 Por. Sozomenus, HE II 17, 11, SCh 306, 302, Kazikowski s. 112: „A gdy Aleksander rozstal się z życiem pozostawiwszy go swym następcą, sława, jaka otaczała Atanazego, wzrosła jeszcze bardziej, umacniana jego cnotami oraz świadectwem wielkiego mnicha Antoniego. Ten bowiem posłusznie przyjmował każde wezwanie nowego biskupa, przybywając do miast i spotykając się z nim dla odwiedzenia kościołów, i wyrażał swą zgodę na wszystkie jego poglądy dotyczące Bóstwa. 
w Tyrze (335) przez zgromadzenie biskupów i zesłanego na mocy dekretu cesarskiego do Trewiru (Galia), za rzekome sianie zamętu, w związku ze sprawą Ariusza (ok. 256-336), a następnie przybyłego osobiście aż do Konstantynopola, by tam dowieść swojej niewinności przed cesarzem ${ }^{4}$. Innym wyrazem troski Konstantyna o życie ascetyczne byl także edykt (wydany przez niego w 320 roku), dotyczący kobiet i mężczyzn wybierających życie w dziewictwie, przy czym ustawa ta przyznawała ascetom nawet pewien przywilej (sporzą-

Poza tym okazywał mu zawsze swą przyjaźń i unikał jego przeciwników czy zdecydowanych wrogów”; tamże II 31, 1-3, SCh 306, 368-370, Kazikowski s. 141-142: „Jednakże nawet po jego smierci nie ustały dociekania nad wymyślonymi przez niego tezami; nie przerwali także swojej dzialalności zwolennicy jego nauki i dalej zastawiali sidła na obrońców tez przeciwnych. W każdym razie, chociaż oczywiście i lud aleksandryjski nieustannie podnosił głos, nawet w uroczystych nabożeństwach błagając o powrót Atanazego, i wielki mnich Antoni niejednokrotnie pisal w jego sprawie, zaklinając władce, by nie wierzył melicjanom i za oszczerstwo uważał ich oskarżenia, cesarz nie dał się przekonać. [...] jednocześnie powtarzał $z$ uporem, że nie cofnie swojej decyzji i nie odwola Atanazego z wygnania, jako buntownika, i to skazanego z ramienia sądu Kościoła. Odpowiadając zaś Antoniemu dał do zrozumienia, że on, cesarz, nie może sobie lekceważyć orzeczenia synodu. Bo jeżeli nawet ci i owi - pisał do niego - rozsądzając sprawę kierowali się niechęcią czy sympatią, to przecież jest wprost nie do pomyślenia, aby tego rodzaju nastawienie miała olbrzymia rzesza wykształconych i pobożnych biskupów. Bo, co dotyczy Atanazego, jest on pyszałkiem i człowiekiem, który nie przebiera $w$ słowach, $i$ to on ponosi winę za niezgodę i niepok6j".

${ }^{4}$ Por. Socrates, HE I 28, 1-4, GCS N.F. 1, 79, Kazikowski s. 136-137: „Otóż kiedy zdążając na synod biskupi zebrali się przypadkowo najpierw w Tyrze, cesarz polecił im zapoznać się ze sprawą Atanazego, aby tam na miejscu usunąwszy zawczasu przedmiot sporu, z większym spokojem mogli potem dopełnić obrzędów dedykacji kościoła, skoro mają go poświęcić Bogu. Przypadał wtedy trzydziesty rok rządów Konstantyna. Przybyli zatem do Tyru biskupi z różnych miejscowości, a zebrało się ich sześćdziesięciu za sprawą namiestnika Dionizjusza, męża konsularnego. Przywieziono również pod eskortą wojskową zakutego w kajdany Makarego, prezbitera z Aleksandrii. Atanazy natomiast chciał zrazu uniknąć spotkania, nie tyle ze strachu przed oskarżeniami - bo nic nie wiedzial na temat treści oskarżeń - ile z obawy przed próbą wprowadzenia jakichś zmian naruszających postanowienia soboru w Nicei. Jednakże przejał go lękiem brzemienny groźbą list od cesarza: otrzymal bowiem pismo, że jeżeli nie stawi się dobrowolnie, zostanie sprowadzony na miejsce w trybie karnym. Przybyl tedy pod przymusem rowniez i Atanazy"; Sozomenus, HE II 25 , 14-15, SCh 306, 342, Kazikowski s. 129-130: „Atanazy ze swej strony doszedłszy do wniosku, że dalszy pobyt $w$ Tyrze przedstawia dla niego wielkie niebezpieczeństwo, a szukanie sprawiedliwości przeciw tłumowi oskarżycieli u wrogo usposobionych sędziów również nie oznacza nic pewnego, uszedł do Konstantynopola. Synod jednakże wymierzył mu karę zaocznie, pozbawiając go biskupiego urzędu i uchwalając, że skazanemu nie będzie odtąd wolno mieszkać w Aleksandrii, aby - jak glosi wyrok - pojawiwszy się na miejscu nie zaczął wywoływać wrzenia i rozruchów"; tamże II 28, 1 i 14, SCh 306, 356 i 360, Kazikowski s. 135 i 138: „Uciekając z Tyru przybył Atanazy do Konstantynopola; i wystąpiwszy przed cesarzem Konstantynem, w obecności biskupów, tych, którzy ogłosili przeciw niemu wyrok potępiający, z żalem opowiedzial o krzywdzie, jaka go spotkała, i prosił, aby orzeczenia wydane $w$ Tyrze przebadano w obecności samego cesarza. Konstantyn uznając żądanie za uzasadnione napisał do biskupów zgromadzonych w Tyrze [...]. Cesarz ze swej strony, czy to przekonany, że tego rodzaju oskarżenia opierają się na prawdzie, czy też wierząc, że biskupi osiągną na przyszłość trwałe porozumienie, jeśli tylko usunie Atanazego, skazał biskupa na pobyt w Trewirze, mieście położonym na Zachodzie, w Galii. Tam więc wywieziono skazańca". 
dzanie prawnego zapisu testamentalnego przed osiągnięciem pełnoletności) ${ }^{5}$. Kontynuując nasze rozważania, trzeba podkreślić, że z rodziną cesarską, dworem cesarskim, czy też z administracją bizantyńską związani byli wysokiej rangi urzędnicy państwowi, którzy po swoim nawróceniu prowadzili życie pustelnicze m. in. w Egipcie. Wśród nich na szczególną uwagę zasługuje Arseniusz (ok. 354-449), pochodzący $z$ arystokratycznej rodziny rzymskiej (urodził się i wychowal w Rzymie), później zaś przebywał w Konstantynopolu na dworze Teodozjusza Wielkiego (cesarz w latach 379-395), gdzie był wychowawcą synów tegoż cesarza, Arkadiusza, późniejszego cesarza Wschodu (395-408), oraz Honoriusza, późniejszego cesarza Zachodu (395-423), a następnie udał się na pustynię Sketis w Egipcie (ok. 394/395) i prowadził tam życie pustelnicze ${ }^{6}$.

5 Por. Sozomenus, HE I 9, 1-4, SCh 306, 150-152, Kazikowski s. 48-49: „Obowiązywala wsród Rzymian starodawna ustawa, wzbraniająca żyjącym w bezżennym stanie poczynając od lat dwu. dziestu pięciu korzystania $z$ tych samych uprawnień, z których korzystają inni. Zakaz dotyczyl zarówno wielu innych szczegółów, jak i zabraniał korzystania z zapisów testamentowych, o ile obdarowany nie nalezal do najbliższych krewnych; bezdzietnych zaś ustawa karała utrata połowy masy spadkowej. Starożytni Rzymianie oglosili to prawo w nadziei, że Rzym i podlegle mu obszary wzrosną w liczbę ludności, jako ze akurat na krótko przed uchwaleniem ustawy utracili wielu obywateli w rezultacie wojen domowych. Otóż cesarz widząc, że na skutek tej ustawy pokrzywdzeni są ci, którzy dla milości Bożej żyją w dziewiczym stanie i wyrzekają się potomstwa, uznał za naiwność przekonanie, iż w wyniku starania i wysiłku ludzi może wzrosnąć liczebnie ich ród, podczas gdy przyroda otrzymuje zarówno wyrok zatraty, jak i siłę wzrostu zawsze według miary odmierzonej ręką Bożą. Dlatego też ogłosił ludowi ustawę przyznająca tym, co nie wstępują w związki małżeńskie, i tym, co nie mają dzieci, korzystanie z takich samych uprawnień, z jakich korzystają wszyscy po równi. Wszelako nawet więcej przyznał swą ustawą żyjącym we wstrzemięźliwości cielesnej i w dziewictwie, gdyż dał im prawo, tak mężczyznom, jak i niewiastom, sporzadzania zapisów testamentowych, choćby jeszcze nie osiągneli pelnoletności, co było wbrew panującemu powszechnie w państwie rzymskim zwyczajowi. Był bowiem przekonany, że ci, którym chodzi zawsze tylko o cześć Bożą i ćwiczenie się w cnotach chrześcijańskich, trafne znajdą decyzje we wszystkich sprawach. Przecież moment ten uwzględniali także i starożytni Rzymianie, kiedy powzięli uchwałę, że dziewicom Westy, choćby i w wieku lat sześciu, wolno bez przeszkód sporządzać testament"; pierwsza część cytatu I 9, 1-2, odnosi się do ustawy zwanej Lex Julia et Pappia Poppaea de maritandis ordinibus z roku 9 po Chrystusie, uchwalonej na wniosek konsula Marka Papiusa i Poppeusa Sabina; natomiast druga część cytatu, I 9, 3-4, jest to streszczenie przez Sozomena interesującego nas edyktu wydanego przez Konstantyna Wielkiego 31. I. 320 r. na Sardyni, a znajdującego się w Codex Theodosianum VIII 16, 1.

${ }^{6}$ Por. Apophthegmata Patrum, series alphabetica 1(39) (Arseniusz), PG 65, 88BC, ŹM 4, 136 : „Abba Arseniusz, kiedy żył jeszcze w pałacu cesarskim, modlił się do Boga: «Panie, zaprowadź mnie na drogę zbawienia». I usłyszał głos mówiący: «Arseniuszu, uciekaj od ludzi, a będziesz zbawiony»; tamże 2(40): Arseniusz, PG 65, 88C, ŹM 4, 136: „Ten sam, kiedy już odszedł na pustynię, znowu się modlił tymi słowami, i znowu usłyszał głos: «Arseniuszu, uciekaj, milcz, mód! się: to są bowiem korzenie bezgrzeszności»; tamże 4 (42): Arseniusz, PG 65, 88C, ŹM 4, 136 : „Opowiadano o nim, że jak w pałacu nikt nie nosił strojniejszych szat od niego, tak na pustyni nikı nie przychodzil do kościoła gorzej ubrany"; tamże 6 (44): Arseniusz, PG 65, 89A, ŹM 4, 137: „Kiedy raz abba Arseniusz radził się pewnego starca Egipcjanina co do swoich myśli, ktoś inny zobaczył to i zapytał: «Abba Arseniuszu, jakże to ty, który otrzymałeś tak wielkie wykształcenie w grece i lacinie, radzisz się tego prostaka co do swoich myśli?» On zaś mu odpowiedzial: «w grece 


\section{Nieznanym z imienia mnichem żyjącym w Egipcie był także były prefekt pretorium ${ }^{7}$. Ponadto zakonnicy egipscy udawali się niekiedy do Konstantyno-}

i lacinie mnie wykształcono, ale alfabetu tego prostaka jeszcze się nie nauczyłem»"; tamże 12 (50): Arseniusz, PG 65, 89CD, ŹM 4, 138: „Powiedział abba Arseniusz, że mnich przebywający w obcym kraju nie powinien się do niczego mieszać, a znajdzie pokój”; tamże 18 (56): Arseniusz, PG 65, 92C, ŹM 4, 139: „Mówiono też o abba Arseniuszu, że tylko raz do roku zmieniał wodę, która mu służyła do zwilżania włókien, a przez cały rok tylko do niej dolewał. Plótl bowiem liny i szył kosze codziennie do godziny szóstej. A starcy prosili go i mówili: «Czemu nie zmienisz wody, przecież cuchnie». On odpowiadał: "To za kadzidła i wonie, którymi rozkoszowałem się w świecie, muszę teraz znosić ten zaduch»; tamże 29 (67): Arseniusz, PG 65, 97BC, ŹM 4, 143: „Abba Daniel opowiadał o abba Arseniuszu, że kiedyś przyszedł urzędnik i przyniósł mu testament jakiegoś krewnego senatora, który zostawil mu ogromny spadek. Starzec wziąl ten testament i chcial go podrzeć. Wtedy urzędnik padł mu do nóg i mówil: «Błagam cię nie drzyj go, bo mi głowę utną!» Odrzekł abba Arseniusz: "Ja umarłem wcześniej, a on dopiero teraz». Odesłał więc testament i nic nie przyjął”; tamże 36 (74): Arseniusz, PG 65, 101D-104A, ZM 4, 147: „Wtedy rzekł kapłan: "Widzisz tego oto abba Arseniusza? On w świecie dla cesarzy był jak ojciec: służyły mu tysiące niewolników, wszyscy w jedwabnych szatach, w złotych pasach i w klejnotach, a spoczywal na bezcennych posłaniach. Ty jako pasterz nie miałeś w świecie tak dobrze, jak tu masz teraz: on zaś nie ma już tutaj takich wygód, w jakich żył w świecie. I tak ty doznaleś ulgi, a on utrapienie». Gdy starzec to usłyszal, przejął się skruchą i powiedział, padłszy mu do nóg: «Wybacz mi, abba, zgrzeszyłem: to jest prawda niewątpliwie, że on tu przyszedł na uniżenie, a ja na polepszenie losu». I odszedł zbudowany”; tamże 42 (80): Arseniusz, PG 65, 108A, ŹM 4, 150: „Brodę miał długą do pasa, a rzęsy wypadały mu od łez: był wysoki, ale na starość się zgarbił. Żył lat dziewięćdziesiąt pięć: $\mathrm{z}$ tych czterdzieści przebył w pałacu świątobliwej pamięci Teodozjusza Wielkiego, gdzie był jak ojciec dla najjaśniejszych Arkadiusza i Honoriusza. Potem w Sketis mieszkał przez lat czterdzieści, potem dziesięć w Troe powyżej Babilonu, naprzeciw Memfis: trzy w Kanopos koło Aleksandrii, a ostatnie dwa znowu w Troe, i tam umarl"; tamże 1 (799): Rzymianin, PG 65, 385CD-388CD, ŹM 4, 431-433: „Pewien wielki dostojnik cesarski z Rzymu został kiedyś mnichem i zamieszkał w Sketis niedaleko kościoła; [...]. A gdy przemieszkał już w Sketis dwadzieścia lat, zasłynął z daru widzenia. [...] zaczął mu opowiadać o swoim własnym życiu w świecie, bo mu chciał pomóc. I mówil: «A ja nędzny, którego tu widzisz, pochodzę $z$ wielkiego miasta Rzymu, i byłem tam w pałacu cesarskim jako dostojnik». [...]. A starzec ciągnął: «I opuściłem miasto, a przybyłem na tę pustynię. I dalej, ja, którego tu widzisz, miałem wspaniałe domy i wielkie bogactwa: a pogardziwszy nimi, przybyłem do tej małej celki. I jeszcze miałem ja, którego tu widzisz, łoża ze szczerego złota i na nich kosztowne posłania, a na ich miejsce dal mi Bóg to proste posłanie i tę skórę. A szaty moje bywały bardzo kosztowne: zamiast nich noszę teraz tanią suknię. Na moje uczty wydawano wiele złota, a na ich miejsce dal mi Bóg tę trochę jarzyn i kubeczek wina. Usługiwali mi liczni niewolnicy, a oto na ich miejsce Bóg pobudzil tego oto staruszka, aby mi służył. A zamiast łaźni wylewam sobie trochę wody na nogi, noszę także sandały z powodu mojej słabości. A zamiast muzyki i cytr odmawiam te dwanaście psalmów»; K. S. Frank, Arsenios der Grosse. Vom Apophtegma zum hagiographischen Text, w: Mémorial Dom J. Gribomont, Roma 1988, 271-287; H. Fros, EK 1 (1973) 952; S. Kazikowski, w: Sokrates Scholastyk, dz. cyt., s. 360, przypis 89 do Hislorii Kościota IV 23; M. van Parys, La lettre de S. Arsène, Ir 54 (1981) 62-86.

${ }^{7}$ Por. Apophthegmata Patrum, ser, alphabetica 5 (439): Kronios, PG 65, 249BC, ŹM 4, $298-$ 299: "Czemu ty zawsze przychodzisz tu tak ubrany»? A on odpowiedzial: «Wybacz mi, abba: nie mam nic innego". Więc zabrałem go do swojej celi i dałem mu tunikę i wszystko inne, czego potrzebowal; i odtąd ubierał się tak, jak inni bracia, a wyglądem przypominał aniola. [...]. Kiedy się dowiedzial, upadl na twarz przed ojcami, mówiąc: «Na Boga, wybaczcie mi: jestem niewolnikiem pewnego tamtejszego dostojnika $i$ jeśli on mnie pozna, to mi odbierze habit i zmusi znowu do 
pola $w$ celu uzyskania u cesarza $\mathrm{m}$. in. zwolnienia od podatków ${ }^{8}$, czy też z prośbą o ułaskawienie dla żołnierza gwardii cesarskiej (popadł on w niełaskę u samego władcy), czego dokonał mnich Eutychian, należący do wspólnoty kościelnej nowacjan i prowadzący życie pustelnicze w górach Olimpu, w Bitynii ${ }^{9}$. Zdarzały się też przypadki, iż tamtejsi (egipscy) pustelnicy obdarzeni darem przewidywania przyszłości, wspierali radą cesarzy (m. in. Teodozjusza

slużby». Tak uprosił ojców i zostawili go, a dopiero potem dowiedzieli się od kogos, kto go znal dobrze, że kiedy był jeszcze w świecie, był prefektem pretorium; więc tamto zmyślił po to, żeby go nie poznano i żeby ludzie mu się nie naprzykrzali”.

8 Por. Apophthegmata Patrum, ser. alphabetica (154): Ammonatas, PG 65, 136D-137AB, ŹM 4, 179-180: „Pewien urzędnik przybył do Peluzjum i chciał ściągać poglówne z mnichów tak samo, jak ze swieckich. Wszyscy bracia zebrali się w tej sprawie u abba Ammonatasa, i niektórzy z ojców radzili udać się do cesarza. Abba Ammonatas powiedział im: «Nie potrzeba takiego trudu: raczej trwajcie w skupieniu u siebie i pośćcie przez dwa tygodnie, a za łaską Chrystusa ja sam to załatwię». Bracia rozeszli się więc do siebie, a starzec także trwał na modlitwie we własnej celi. Gdy już przeszło dni czternaście, bracia byli ze starca niezadowoleni, bo wiedzieli, ze się nigdzie nie ruszał. I mówili: «Starzec zaniedbał sprawę». A piętnastego dnia zeszli się według umowy, starzec zaś przyszedł $\mathrm{z}$ listem z pieczęcią cesarską. Na ten widok zdumieli się bracia i pytali: «Kiedy go przyniosłeś, abba?» Odrzekł im starzec: «Wierzcie mi, bracia, że tej nocy udałem się do cesarza, on zaś napisał ten list; potem przybyłem do Aleksandrii, gdzie go potwierdzili urzędnicy, a potem tu wróciłem». A oni przerazili się i padli przed nim na twarz; sprawa została załatwiona i ów urzędnik więcej im się nie naprzykrzał”; tamże 5 (439): Kronios, PG 65, 249B, ŹM 4, 299: „Otóż zdarzyło się kiedyś, że ojcowie musieli poslać dziesięciu braci w jakiejś sprawie do cesarza: i wśród innych wybrano do tej delegacji także jego".

${ }^{9}$ Por. Socrates, HE I 13, 1-7 i 9-10, GCS N.F. 1, 44-46, Kazikowski s. 103-104: „Styszałem również o Eutychianie, mężu miłującym Boga, a żyjącym i działającym w tym samym okresie. I on również, chociaż należal do społeczności kościelnej nowacjan, budzil ogólny podziw dokonując czynów podobnych do opisanych przed chwilą. A kto jest źródłem informacji na jego temat, powiem sumiennie i nie będę się z tym krył, choć może się komu narażę. Byl to niejaki Auksanon, prezbiter Kościola nowacjan, starzec sędziwy, który razem z Akezjuszem jako całkiem młody chłopiec przybył na Sobór Nicejski, a później opowiedział mi również to, co przytoczyłem o Akezjuszu. Żył on od tamtych czasów poczynając od rządów Teodozjusza Młodszego, i kiedy ja byłem jeszcze bardzo młody, opowiedział mi o zdarzeniach dotyczących Eutychiana, przytacza. jąc wiele faktów świadczących o tym, że laska Boża mieszkała w jego sercu. Szczególnie jeden z nich zasługuje na pamięć, a miał się wydarzyć za rządów cesarza Konstantyna. Pewien żołnierz z gwardii przybocznej, jeden z tych, których cesarz nazywa «domownikami», podejrzany o jakieś samowolne i uzurpatorskie pociągnięcia, zbiegl. Cesarz pod najsurowszym rygorem nakazal, żeby zgładzono zbiega, gdziekolwiek się znajdzie. Tymczasem ten, schwytany w górach Olimpu w Bitynii, bezlitośnie zakuty został w ciężkie kajdany i wtrącony do więzienia w tej części Olimpu, gdzie równiez przebywał Eutychian. [Bogobojny mąż] prowadzil surowe życie pustelnicze i zajmował się pielęgnacją chorych, a w niejednym wypadku leczył także dusze ludzkie. Był tam z nim razem również i ów dhugowieczny Auksanon, wtedy bardzo młody jeszcze, i uczył się od pustelnika życia monastycznego. Do tego więc Eutychiana przyszła liczna grupa ludzi z błaganiem, by zechciał wyswobodzić więźnia poprzez swoje wstawiennictwo u cesarza. Zdążyły już bowiem dotrzeć do uszu cesarskich wieści o cudach, jakich dokonał Eutychian. Mnich chętnie przyrzekl, że uda się do cesarza. [...]. Następnie Eutychian przybył razem z Auksanonem do dawniejszego Byzantion, a późniejszego Konstantynopola, i tam dopuszczony na cesarskie pokoje wybawił człowieka od śmierci. Cesarz bowiem, powodowany czcią dla męża, chętnie się przychylił do jego prosby". 
Wielkiego) ${ }^{10}$. Tak więc już dosyć wcześnie zostały nawiązane kontakty między Konstantynopolem a mnichami egipskimi. Kolejne więzy Konstantynopola z mnichami z egipskimi miały już nieco inne podłoże. Nasze rozważania rozpoczniemy od następującego zdarzenia. Otóż, ok. 400 roku, arcybiskup Aleksandrii Teofil, kazał opuścić mnichom, tzw. Wielkim lub Wysokim Braciom (ze względu na ich wysoki wzrost) z Nitrii (w Egipcie) miejsce ich dotychczasowego przebywania (Sketis), a nawet Egipt, z powodu jego zatargu $z$ ich przyjacielem, kaplanem Izydorem, którego arcybiskup Teofil niesłusznie oskarżył m.in. o oszczerstwo (krzywoprzysięstwo) wypowiedziane pod jego adresem, a którego oni przyjęli do swojej wspólnoty, oraz ze względu na ich sympatię dla dzieł Orygenesa ${ }^{11}$. Mnisi ci

${ }^{10}$ Por. Palladius, Historia Lausiaca 35, 1-3, ed. G.J.M. Bartelink: Palladio, La storia Lausiaca, introduzione di Christine Mohrmann, testo critico, commento e traduzione di Marino Barchiesi, Vite dei Santi II, Verona 1974, 168, thum. S. Kalinkowski, ŹM 12, Kraków 1996, 162-163: „W Lykopolis mieszkał pewien Jan, [...] otrzymał dar przewidywania przyszłości. Między innymi wysłał kilka przepowiedni blogosławionemu cesarzowi Teodozjuszowi, na przykład o tym, ze pokona tyrana Maksymusa i odzyska Galię; przepowiedział mu również sukces w walce z tyranem Eugeniuszem. Sława o jego cnocie rozeszła się szeroko. Kiedy przebywaliśmy na Pustyni Nitryjskiej, ja i bracia z otoczenia błogosławionego Ewagriusza, gorliwie staraliśmy się poznać cnotę tego męża".

${ }^{11}$ Por. Sulpicius Severus, Dialogus I 6, 1, CSEL 1, 157, tlum. P.J. Nowak. ŹM 8, Kraków 1995 , 115: „przybyliśmy do Aleksandrii. Dochodziło tam do gorszących starć między kaplanami a mnichami. Przyczyną, jak się wydaje, było postanowienie biskupów, którzy zebrani wielokrotnie na różnych synodach, zakazali czytania i posiadania dziel Orygenesa"; tenże, Dialogus I 7, 1-2, CSEL 1, 158-159. ŹM 8, 116: „największe chyba wzburzenie wywołał ten fragment, [...] jakoby Pan Jezus, wcieliwszy się dla odkupienia człowieka, [...] miał odkupić również szatana. [...] powstał spór. [...] odwołano się do pomocy prefekta. Ten zaś, siejąc postrach rozproszył braci"; Socrates, HE VI 7, 22, GCS N.F. 1, 324, Kazikowski s. 463; „Mianowicie przesłał do klasztorów pustelniczych okólnik, że nie należy słuchać Dioskora ani jego braci, gloszących, że Bóg jest istotą bezcielesną"; Sozomenus, HE VIII 11, 1-5, GCS 50, 363-364, Kazikowski, 543: „W tym samym czasie rozgorzala w Egipcie na dobre nieco wcześniej wszczęta debata na temat, czy należy przyjąć pogląd, że Bóg ma postać czlowieczą. Tego właśnie zdania była większość tamtejszych mnichów, którzy w swej prostoduszności brali słowa Pisma Świętego bez badania jego sensu przenośnego i przyzwyczajeni byli sluchać o Bożych oczach, o Jego obliczu, o rękach i innych tego rodzaju sprawach. Wręcz przeciwne zapatrywania mieli ci, którzy uwzględniali myśl ukrytą w słowach, uważając po prostu za bluźnierców przeciw Bogu tych wszystkich, co rozprawiają o takich rzeczach. Sam nawet Teofil nawolywał w kościele do wytrwania przy tym stanowisku, a w swym liście pasterskim, który zgodnie z przyjętym obyczajem napisał o paschalnym święcie, obszernie tłumaczył, że o Bogu myśleć trzeba jako o istocie bezcielesnej i nie lączyć Go z wyglądem człowieka. Ale gdy się o tym dowiedzieli mnisi egipscy, przybyli do Aleksandrii; za czym połączywszy się w jedną gromadę podnieśli bunt i planowali zgladzić Teofila jako bezboznika. Teofil tymczasem otwarcie wystąpiwszy wobec nich, w momencie kiedy jeszcze się burzyli, powiedział: «Widzę was tak, jak widzę oblicze Boga». Zdanie to wystarczyło, by utrzymać mnichów w szachu. I ochłonąwszy z gniewu oznajmili: «Jeśli naprawdę w to wierzysz, wyklnij zatem księgi Orygenesa, ponieważ to one właśnie uczą swoich czytelników tak bezbożnie myślećn. A Teofil im na to: «Ależ ja juz dawno uznalem to za sluszne i postąpię tak, jak tego chcecie; bo i ja tak samo mam żal do tych, którzy przyjmują poglądy Orygenesa». I tak oto omamiwszy mnichów rozładował Teofil buntownicze nastroje"; tamże VIII 12, 1-7, GCS 50, 364-365, Kazikowski s. 544-545: „I być może debata byłaby wtedy całkiem ucichła, gdyby już po tej przerwie nie poruszył jej dla prywatnej swej nienawiści Teofil, knując przeciwko Ammoniosowi i Dioskorowi oraz Euzebiuszowi i Eutymio- 
po opuszczeniu Egiptu przybyli do Konstantynopola, gdzie zostali życzliwie przyjęci przez św. Jana Chryzostoma ${ }^{12}$. W związku z tą sprawą przybył do Konstantynopola również św. Epifaniusz, biskup Salaminy (ok. 315-403), występujący wyraźnie przeciwko poglądom zawartych w pismach Orygenesa ${ }^{13}$.

sowi, zwanym Wielkimi. Z wcześniejszych relacji dowiedzieliśmy się już o nich jako o rodzonych braciach, którzy zasłynęli w środowisku ascetów w Scetis. Cieszyli się oni względami Teofila w daleko większym stopniu anizeli inni mnisi egipscy; poza tym biskup często zapraszał ich na rozmowy i traktowal ich jak swoich domowników. Dioskora uczynił nawet biskupem Hermopolis. Nienawiść do nich powziął Teofil na skutek zatargu z Izydorem; tym właśnie Izydorem, którego usilnie starał się wprowadzić na tron biskupi Konstantynopola po śmierci Nektariosa. Oto jak mówią niektórzy, pewna niewiasta $z$ sekty manichejskiej przeszła na lono Kościola powszechnego. Teofil postawil w związku z tym zarzut ówczesnemu archiprezbiterowi, że kobieta uczestniczyła bezmyślnie w tajemnicach wiary, nim się wyrzekła poprzedniej herezji; nienawidzil go zresztą $z$ innych jeszcze powodów. Tymczasem Piotr - tak bowiem mial na imię ów archiprezbiter - z naciskiem podkreślal, że niewiasta dostạpila wspomnianego uczestnictwa zarówno w zgodzie z prawem kościelnym, jak i za wiedzą Teofila, a na świadka obu tych faktów powoływał Izydora. Ten ostatni przypadkowo posłował podówczas do Rzymu, lecz kiedy wrócił, poświadczył, że Piotr mówi prawdę. Oburzony tym Teofil jako rzekoma ofiara oszczerstwa - usunął obydwu z Kościoła. Tak zatem mówią niektórzy. [...] zdołałem się dowiedzieć, że Teofil dwa miał powody, aby znienawidzić Izydora: jeden, wspólny w przypadku Izydora i prezbitera Piotra, to ten, że obaj odmówili zlożenia przysięgi, jakoby siostra Teofila zapisana została przez kogoś jako spadkobierczyni: drugi powód, dotyczy wyłącznie Izydora. to ten, że gdy na ręce prezbitera jako opiekuna biednych składano mnóstwo pieniędzy i Teofil zamierzał wziąć $z$ tego pewną sumę, tłumacząc się poczynionymi wydatkami na budowę kościolów, on się na to nie zgodzil: bo lepiej, jak mówil, otoczyć należytą opieką ciała ludzi chorych i znękanych nieszczęściem, które bardziej zasługują na to, by je nazywać świątyniami Boga - i ze względu na które dostarczano pieniędzy - aniżeli wznosić murowane ściany. Ale czy to z tego powodu, czy też z innego, dość, że Izydor, usunięty przez Teofila poza nawias życia we wspólnocie, przybyl do Sketis, do tamtejszych mnichów, jako do swych towarzyszy".

12 Por. Hieronymus, Epistula 113, 1 (Epistula Theophili), CSEL 55, 393-394, thum. J. Czuj, Sw. Hieronim, Listy, III, Warszawa 1954, 41: „Jan, który do niedawna kierował kościolem konstantynopolitańskim, [...] dopuścił do zażyłej przyjaźni ze sobą zwolenników Orygenesa i bardzo wielu $\mathrm{z}$ nich ułatwił uzyskanie godności kapłańskiej. Przez tę zbrodnię pogrążył w wielkim smutku Epifaniusza, [...] który zabłysnął wśród biskupów, jak jasna gwiazda na firmamencie": Sozomenus, HE VIII 13, 1-2, GCS 50, 366, Kazikowski s. 547: „Dioskor i Ammonios oraz ci, co byli z nimi, przejrzawszy zasadzkę, uszli do Jerozolimy, [...]. Dowiedziawszy się o tym planie. Ammonios i towarzyszący mu mnisi odpłynęli do Konstantynopola, a z nimi razem - także Izydor"; Socrates, HE VI 9, 1-2 i 9-10, GCS N.F. 1, 326-327, Kazikowski s. 466-467: „Wkrótce potem mnisi z pustelni wraz z Dioskorem i jego braćmi przybywają do Konstantynopola. Towarzyszył im również Izydor, dawniejszy ulubieniec biskupa Teofila, [...]. To było przyczyną, dla której również Izydor przybył do Konstantynopola razem z mnichami towarzyszącymi Dioskorowi; chcial, aby uknute przeciwko nim nikczemne intrygi mogły być rozpatrzone zarówno wobec cesarza, jak i wobec biskupa Jana. Jan, gdy się o tym wszystkim dowiedzial, potraktowal przybyłych z należytym szacunkiem": Palladius, Historia Latsiaca 1, 1, ed. Bartelink s. 18, ZM 12, 78: „Był to kapłan Izydor, [...]. Gdy go spotkałem, miał już siedemdziesiąt lat, a żył potem jeszcze lat piętnaście i zmarł w pokoju" (zmarl w Konstantynopolu ok. 403 r.); J.N.D. Kelly, Golden Mouth. The Story of Jolun Chrysostom - Ascetic, Preacher, Bishop, London 1995, 190-202.

${ }_{13}$ Por. Socrates, HE VI 12. 1 i 3, GCS N.F. 1, 333, Kazikowski s. 472-473: „Wkrótce potem do Konstantynopola ponownie przybyl z Cypru biskup Epifaniusz, przekonany co do dobrych intencji 
Należy tu jeszcze dodać, iż z dworem cesarskim związany był pewien Marcjan, pochodzący $z$ rodziny arystokratycznej z Cyru, który zrezygnowal jeszcze jako młodzieniec $z$ otwierająccj się przed nim wspaniałej kariery zawodowej i został eremitą na pustyni Chalkis w Syrii, za panowania cesarza (Wschodu) Walensa (364-378) ${ }^{14}$. Ponadto spośród urzędników administracji cesarskiej, także Zenon, który nalcżał do korpusu agentes in rebus i był kurierem cesarskim pełniącym jednocześnie funkcję szpiega i policjanta (formacja ta została założona przez Konstantyna Wielkiego, a około 345 r. nadzorowała wyższych urzędników oraz ich biura, kontrolowała też pocztę na prowincji) po śmierci cesarza Walensa poświęcil się życiu monastycznemu w Syrii ${ }^{15}$. Na-

Teofila, i przywiózł ze sobą na piśmie uchwały potępiające dzieła Orygenesa; jak to już powiedzialem, Epifaniusz nie wyklinat w nich samego autora, a tylko odrzucał jego rozprawy. [...]. Chcąc zaś wyświadczyć przysługę Teofilowi, uchylił się od przyjęcia zaproszenia od Jana"; Sozomenus, HE VIII 15, 3 i 5, GCS 50, 369-370, Kazikowski s. 552-553: „Tymczasem Ammonios i towarzyszący mu mnisi przybyli do Epifaniusza; taka bowiem była wola samej cesarzowej. Na jego pytanie, co za jedni, odpowiadając rzecze Ammonios: «To my, Ojcze, Wielcy Bracia»! [...]. Tym razem Epifaniusz przemówił z większym umiarem, nim się z nimi rozstał. Niedługo potem odpłynął na Cypr, [...] mając sobie za zle, że w ogóle przyjeżdzal do Konstantynopola".

${ }^{14}$ Por. Theodoretus, Historia religiosa III 2-3 i 14, SCh 234, 248-250 i 274-276, thum. K. Augustyniak, ŹM 7, Kraków 1994, 100-102 i 110-111: „Wzgardzil on sławą rodu - pochodził bowiem $z$ rodziny arystokratycznej - a także wspaniałością dworu cesarskiego, gdzie roztaczał urok młodości, gdyż otrzymał od Stwórcy natury wysoki wzrost, piękne ciało i duszę ozdobioną mądrością, calą natomiast swoją miłość skierował ku Bogu i sprawom Bożym. [...] i słuchał Jego słodkiego głosu. Kiedy bowiem czytal boskie slowa, sądził, że cieszy się głosem Boga, a kiedy się modlił i zanosit do Niego prośby, sam nawiązywał rozmowę z Panem. W korzystaniu z tego rodzaju rozkoszy nigdy nie znał miary, [...]. Sięgając po te owoce, oddał się najsłodszemu z trudów: po modlitwie następowała psalmodia, po psalmodii modlitwa, a po jednym i drugim czytanie słowa Bożego. [...]. Lepiej zatem - twierdził - jeść codziennie, ale nigdy do syta, gdyż prawdziwy post to ustawiczny głód. Takiej zasady trzymał się stale ten Boży mąż i chociaż był bardzo rosły, a nawet największy i najpiękniejszy spośród wspólczesnych sobie ludzi, żywił swoje ciało małą ilością pokarmu. [...]. Przybyła kiedyś do niego z ojczyzny jego siostra ze swym synem, który był już dorosłym człowiekiem i należał do pierwszych obywateli Cyru, i przyniosła mu wiele żywności. On jednak nie zgodził się na widzenie $z$ nią, przyjął natomiast siostrzeńca, akurat bowiem przypadla pora przeznaczona na spotkanie. Kiedy obydwoje prosili go, aby przyją to, co przynieśli, zapytal ich: «Obok ilu klasztorów przeszliście, z iloma z nich podzieliliście się ta żywnością?» Kiedy siostrzeniec odpowiedzial, że nikomu nic nie dali, rzekł: «Odejdźcie z tym, coście przynieśli, gdyż my żadnej z tych rzeczy nie potrzebujemy, a gdybyśmy potrze bowali, to i tak byśmy nie przyjęli, bo ze względu na naturalne pokrewieństwo, a nie ze względu na służbę Bogu okazujecie nam tę życzliwość».

${ }^{15}$ Por. Theodoretus, Historia religiosa XII 1-2, 5 i 7, SCh 234, 460-462 i 468-472, ŹM 7, 179 180 i 182-183: „Mało ludzi zna godnego podziwu Zenona, [...]. Po śmierci Walensa zdjąl pas zolnierski. Był jednym z tych, którzy szybko roznoszą pisma cesarskie. Z pałacu przeprowadził się do grobu [...] pod Antiochią. [...] nie miał ani łózka, ani światła, ani ogniska, ani garnka, ani flaszeczki na oliwę, ani skrzynki, ani książki, ani niczego innego; ubierał się w stare lachmany, [...]. Pożyczał od przyjaciół na raz tylko jedną książkę i gdy ją w całości przeczytal, zwracał ją i dopiero wtedy brał następną. [...]. Smuciło mianowicie go i dręczyło to, że pozostal mu jeszcze majątek. którego nie sprzedal i nie rozdał ubogim zgodnie z prawem Ewangelii (por. Mt 19, 21). Przyczyną 
leży stwicrdzić, że choć nieliczne były przypadki porzucania tak upragnionej przez wielu kariery na dworze cesarskim, czy też związanej z nim administracji i wybrania życia w surowej ascezie, to jednak wydaje się nam, że mogło to mieć pewien wplyw na życia monastyczne w Konstantynopolu. Obok tego również niektóre osoby świeckie, związane w jakiś sposób z życiem mniszym (poprzez kontakty $z$ mnichami), zwłaszcza prowadzące interesy, czy też załatwiające sprawy publiczne, a w związku z tym często się przemieszczające po rozległych ziemiach Cesarstwa Rzymskiego, były tymi, dzięki którym następowała wymiana informacji także o monastycyzmie. Taki właśnie przykład znajdujemy w Apophthegmata Patrum, gdzie wysoki urzędnik z Nikopolis w Palestynie, o imieniu Bakatos, po opuszczeniu ojczyzny, udał się w interesach przez Antiochię (spotkał się tam ze św. Szymonem Słupnikiem) do Konstantynopola ${ }^{16}$ i prawdopodobnie dzielił się tam swoimi spostrzeżeniami na temat monastycyzmu palestyńskiego i syryjskiego, przyczyniając się w jakiś sposób (mniej lub bardziej świadomie) do ubogacenia tej formy życia w stolicy Cesarstwa Wschodniego.

Pierwsze klasztory męskie i żeńskie zostały ufundowane tutaj dosyć późno (ok. 350-360) przez semiariańskiego biskupa Konstantynopola (od 342 r.) Macedoniusza, a opiekę nad tymi wspólnotami sprawował bliski jego wspólpracownik, diakon Maratonios ${ }^{17}$. Na ascetyczne zapatrywania Maratoniosa

tego byla niepełnoletność jego braci, a posiadłości i pieniądze były wspólną wlasnością. Nie chciał osobiście udawać się do kraju rodzinnego, by dokonać podziału majątku, a obawiał się sprzedawać swoją część obcym, aby nabywcy z chciwości nie oszukali bratanków i nie oczernili go. Zastanawial się długo, co powinien uczynić, i odkładał sprzedaż. Wreszcie sprzedał wszystko jednemu z przyjaciól za dużą sumę i większą część swoich pieniędzy rozdał".

16 Por. Apophthegmata Patrum, series alphabetica 2 (177): Gelazy, PG 65, 148ABC, ŹM 4, 192-193: „Temu to abba Gelazemu pewien starzec, również mnich, mieszkający koło Nikopolis. zostawił w spadku swoją celę i przylegle do niej pole. A pewien dzierźawca Bakatosa (który to Bakatos byl wtedy wysokim urzędnikiem w Nikopolis palestyńskiej), krewny zmarłego starca, udal się do tegoż Bakatosa, prosząc, aby to pole jemu przypadło, bo według prawa on był spadkobiercą. Bakatos, ponieważ chodziło o jego sługę, próbował osobiście odebrać to pole od abba Gelazego; ten jednak, nie chcąc oddawać celi mniszej w ręce świeckie, nie opuścil posiadłości. Bakatos wyśledził osły abba Gelazego, wiozące oliwki z odziedziczonego przezeń majątku: silą sprowadzil je do siebie i oliwki zabrał, a ledwo odesłał same osły z poganiaczami, których nadto zelżył. Swięty starzec nie upomniał się o owce, ale prawa do majętności się nie zrzekl, z przyczyny, o której juz powiedzieliśmy. Bakatos zawziął się na niego, a że miał także inne sprawy, bo był pieniaczem. wyruszył do Konstantynopola. Drogę odbywal pieszo. [...] święty Szymon zobaczył go ze swego słupa i zapytał: «Skąd jesteś»? On odrzekł: «Jestem z Palestyny, a idę do Konstantynopola». Święty pytal dalej: «Po co»? Bakatos na to: «W ważnej sprawie; a ufam, że dzięki modlitwom twojej świątobliwości powrócę i pokłonię się znowu do twoich świętych stóp».

17 Por. Sozomenus, HE IV 20, 1-2, SCh 418, 290- 292, Kazikowski s. 255-256: „W czasie kiedy w Italii działy się opisane tu rzeczy, na Wschodzie, zanim zwolano synod w Seleucji, doszło do niesłychanie gwaltownych zaburzeń. I tak oto, Akacjusz i Patrofil, usunąwszy Maksyma, zarząd nad Kościołem jerozolimskim powierzyli Cyrylowi. Pierwszych święceń udzielił mu jeszcze Makary. A znów Macedoniusz wzburzył Konstantynopol i leżące dookoła miasta, mając oddanych sobie 
(również semiarianina), założyciela klasztorów męskich i żeńskich (ok. 370380), miał wpływ Eustacjusz z Sebasty (ok. 300-377). Z kolei Eustacjusz ulegl semiarianizmowi Macedoniusza, twierdzącego co prawda, iż Syn Boży jest współistotny Bogu Ojcu, ale odmawiającego takiej współistotności Duchowi Świętemu, uważając, że Jego funkcja jest podobna mniej więcej do tej, jaką spełniają „posłańcy Boży”, czyli aniołowie ${ }^{18}$. Z tymi to właśnie biskupami, a jednocześnie i mnichami semiariańskimi, Macedoniuszem i Maratoniosem (był on biskupem Nikomedii; początkowo homojuzjaninem, a potem czołowym duchoburcą), oraz z rozpowszechnianą przez nich herezją, a także nieludzkimi metodami, jakimi zwalczali zwolenników wspólistotności, były trudności nie tylko w Konstantynopolu i w jego okolicach, lecz także w sąsiadujących z nim prowincjach (Tracja, Bitynia) ${ }^{19}$. Dlatego też Sobór w Chalcedonie

pomocników w osobach Eleuzjosa i Maratoniosa. Tego ostatniego, jako byłego diakona Kościoła podlegającego biskupiej jego władzy, a zarazem gorliwego nadzorcę przytułków dla biednych oraz prokuratora klasztorów wspólnych dla męzów i niewiast"; M. Kanior, Historia monastycyzmu chrześcijaniskiego, t. 1, Kraków1993, 139.

18 Por. Socrates, HE II 38, 3-4, GCS N.F. 1, 164, Kazikowski s. 240-241: „Macedoniusz natomiast wzburzył sąsiadujące $z$ Konstantynopolem miasta i prowincje wysuwając jako kandydatów pomocników jego własnych poczynań przeciw Kościołom. Na biskupa więc Kyzikos wyświęcil Eleuzjosa, a na biskupa Nikomedii - Maratoniosa, który przedtem by! diakonem, wyznaczonym przez Macedoniusza, a odznaczał się gorliwością w zakresie organizacji męskich i żeńskich klasztorów”; Sozomenus, HE IV 27, 1-5, SCh 418, 340-342, Kazikowski s. 278-279: „Oto bowiem Macedoniusz, pozbawiony władzy nad Kosciołem Konstantynopola, nie wyznawal już poglądów zblizonych do stanowiska obozu Akacjusza i Eudoksjosa. Nauczał zatem, ze Syn jest Bogiem, jak pod każdym innym względem tak $\mathrm{i}$ co do istoty podobnym do Ojca; utrzymywał jednak i dowodził, że Duch Swięty nie ma udziału w tej samej czci i chwale co Bóg Ojciec i Syn Boży. Sługą i podwładnym pomocnikiem Go nazywał i używal tu wszelkich określeń, jakie bez popełnienia błędu móglby zastosować ktoś, kto by mówił o posłańcach Bożych, o aniołach. Tego rodzaju sąd zaczęli na równi z nim podzielać Eleuzjos i Eustacjusz oraz wszyscy inni duchowni, ilu ich tylko było pousuwanych wtedy w Konstantynopolu przez przedstawicieli przeciwnego obozu. Przyłączyła się do nich niemała część ludności zarówno w samym Konstantynopolu, jak i w całej Tracji, Bitynii, Hellesponcie oraz w prowincjach sąsiednich. Bo doprawdy, jeśli chodzi o ich życie moralne, na co szerokie masy są szczególnie uwrażliwione, nie byli to ludzie, którym by można coś było zarzucić. Wszak i na zewnątrz występowali w sposób nakazujący szacunek, i swym zachowaniem przypominali mnichów; umieli poza tym przemawiać, a usposobienie mieli takie, że potrafilo przekonać. Do takich wlaśnie duchownych tej epoki należal podobno i Maratonios. Będąc dawniej z ramienia państwa rachmistrzem prefektury pretorium zebrał niemałe bogactwo, a kiedy służbę swą zakończył, zadbał o założenie przytułków dla chorych i biednych. Potem zaś idąc za radą Eustacjusza, biskupa Sebasty, obral życie ascetyczne i założyl w Konstantynopolu stowarzyszenie mnichów, które od owego czasu istnieje po dziś dzień, zachowywane w całości dzięki przejmowaniu zadań przez kolejne rzesze następców. Otóż opisywanej tu herezji przyszedł on z pomocą z tak wielkim nakladem energii $\mathrm{i}$ swych prywatnych środków materialnych, ze niektórzy maratonianami nazywają zwolenników Macedoniusza, zresztą nie bez racji, jak mi się wydaje"; zob. G. Dagron, Les moines et la ville "Travaux et mémoires" 4 (1970) 229-276; tenże, Naissance d'une capitale. Constantinopole et ses institutions de 330 à 451, Paris 1974, 513-517.

19 Por. Socrates, HE II 38, 5-10 i 40-44, GCS N.F. 1, 164-165 i 168, Kazikowski s. 241 -242 i 244 245: „Ale trzeba już opowiedzieć, w jaki to sposób Macedoniusz wywrócił normalny porządek 
(451), mając na uwadze te i inne ich nadużycia, jakich się dopuścili, uchwalil przeciwko nim odpowiednie kanony dyscyplinarne, mające na celu głównie

w prowincjach i miastach leżących wokół Konstantynopola. On to bowiem objąwszy tron biskupi, jak to już wcześniej powiedzialem, mnóstwo zła wyrządził tym, którzy odrzucali jego poglądy; a prześladował nie tylko obrońców Kościoła [powszechnego], ale i nowacjan, bo wiedział, ze i oni wyznają współistotność. Tak więc i ci doznawali prześladowań, cierpiąc bez ratunku, a ich biskup, któremu na imię było Agelios, musial nawet uciekać, Ponadto wielu spośród wiernych wyróżniających się pobożnością ujęto i poddano torturom, ponieważ nie chcieli uczestniczyć we wspólnej z Macedoniuszem komunii. Po torturach zaś przemocą zmuszali ich do uczestniczenia w sakramencie ołtarza. Oto rozwierając im szczęki kawałkiem drewna, wkładali im do ust komunikanty. Ci, którzy musieli to wytrzymać, uważali podobną kaźń za gorszy rodzaj zemsty aniżeli wszystkie inne. Porywali też kobiety i dzieci i zmuszali je do przyjmowania chrztu z rąk ariańskich duchownych. A jeśliby się ktoś wymawiał czy też w inny sposób się przeciwstawiał, z miejsca następowała chłosta, a po chłoście - pęta i więzienie oraz wszelkie inne oburzające i straszne czyny. Przytoczę jeden czy dwa przykłady zbrodni Macedoniusza i tych, którzy wtedy byli u władzy, aby ukazać słuchaczom ową dzikość i okrucieństwo. Kobietom, które nie mogły znieść uczestnictwa $w$ ariańskiej komunii, ucinali piłą piersi, układając swe ofiary w skrzyniach. Innym znów kobietom te same części ciała przypiekali dotykając je bądź to rozpalonym żelazem, bądź to rozgrzanymi do najwyższego stopnia skorupami jaj. Była to kaźń zupełnie niespotykana, jeśli ją porównamy z torturami praktykowanymi przez pogan, a w dodatku stosowali ją ci, którzy nazywali siebie chrześcijanami! [...]. Jednakże Macedoniusz nic sobie nie robiąc z protestów przeniósł zwłoki cesarza do kościola, w którym spoczywają szczątki męczennika Akacjusza. Kiedy się to stało, do kościoła tego zaczynają napływać skłócone gromady ludzi, tworząc rozgorączkowane zbiegowisko. Skoro tylko jeden naprzeciw drugiego murem stanęły dwa thumy, natychmiast wywiązała się walka wręcz. Zabito tak wielu ludzi, że krwią spłynął caly dziedziniec owej świątyni, a znajdująca się na nim studnia wezbrała krwią, która popłynęła do przylegającego portyku i aż na sam plac przed krużgankiem. Kiedy się o tym nieszczęściu dowiedział cesarz, zapłonął gniewem przeciwko Macedoniuszowi, tak z powodu tych, co zginęli, jak i dlatego, ze poważył się bez jego wiedzy i woli ruszyć $\mathrm{z}$ miejsca prochy jego ojca. Zleciwszy więc troskę o sprawy ziem zachodnich cesarzowi Julianowi, sam wyruszył w drogę na Wschód. Ale o tym, w jaki sposób Macedoniusz został nieco później usunięty $\mathrm{z}$ biskupiego tronu, tę nieznaczną tylko ponosząc karę za cały ogrom zła, opowiem trochę niżej”; Sozomenus, HE IV 20, 2-3, SCh 418, 292, Kazikowski s. 256: „Obaj podobno prowadzili życie nienaganne, ale zawzięcie starali się szkodzić wyznawcom wspótistotności Syna Bożego z Bogiem Ojcem, choć robili to nie w tak niewymyślny sposób jak sam Macedoniusz. Ten bowiem nie tylko skazywał na wygnanie wszystkich, którzy wymawiali się od utrzymywania z nim więzów wspólnoty kościelnej, lecz także wtrącał ich do więzienia i oddawał pod sąd państwowy. W niejednym przypadku nawet przy użyciu siły zmuszał opornych do wspóludziału w życiu kościelnym, a nie ochrzczone jeszcze dzieci i niewiasty porywał przemocą j chrzcil. Co więcej, wielokrotnie burzyl kościoły, zasłaniając się poleceniem cesarza, nakazującym niszczyć świątynie nieustępliwych wyznawców nauki, że Syn Boży wspótistotny jest Bogu Ojcu"; tamże HE IV 27, 5-6, SCh 418, 342-344, Kazikowski s. 279: „Jak się bowiem okazuje, on jeden, Maratonios, potrafił wraz ze swoimi towarzyszami skutecznie przyczynić się do tego, że herezja ta nie wygasła w Konstantynopolu do szczętu. Bo od czasu, gdy Macedoniusza złożono z urzędu, zwolennicy jego nie mieli ani kościołów, ani biskupów aż do objęcia rządów nad cesarstwem przez Arkadiusza. Oczywiście nie pozwalali na to arianie, usuwając z poszczególnych Kościołów wszystkich tych, którzy okazywali się ich przeciwnikami w wierze, i mszcząc się na nich bezlitosnie"; zob. V. Desprez, Poczq̨iki monastycyzmu. Dzieje monastycyzmu chrześcijańskiego do Soboru Efeskiego (431), thum. J. Dembska, t. 2, ŹM 22, Kraków 1999, 20. 
podporządkowanie mnichów pod jurysdykcję biskupów ${ }^{20}$, a także zabronił im zajmować się sprawami niezgodnymi $z$ ich powołaniem, zwłaszcza wstępować w związki małżeńskie (dotyczyło to także dziewic) ${ }^{21}$. Kolejnym przykładem

${ }^{20}$ Por. Concilium Chalcedonense can. 4, CCO IX 1,1, 72-74, tłum. T. Wnętrzak, ŹMT 24 (Dokumenty soborów powszechnych, I, red. A. Baron - H. Pietras, Kraków 2001), 229: „Mnichom nie wolno nic czynić wbrew woli własnego biskupa, budować klasztoru ani zajmować się sprawami światowymi. [...]. Przeto synod postanowil, aby nikt, w żadnym miejscu, nie budował ani nie zakładal klasztoru czy domu modlitwy wbrew woli biskupa miasta. Ponadto mnisi, w każdym mieście i wsi, mają być podporządkowani biskupowi, [...]. Trzeba w końcu, aby biskup miasta nadzorowal klasztory ze szczególną dokładnością"; tamże can. 8, CCO IX 1, 1, 75-76, ŹMT 24, 233: „klasztory podlegają władzy biskupów. [...]. Tych, którzy ośmielają się w jakikolwiek sposób zakłócać ten doskonały porządek i nie podporządkowują się swemu biskupowi, [...] jeśli są mnichami [...] mają być wyłączeni ze wspólnoty"; tamże can. 24, CCO IX 1,1,88, ŹMT 24, 247: „Klasztory nie mogą stawać się domami prywatnymi. Klasztory, raz poświęcone za zgodą biskupa, mają na zawsze pozostać klasztorami, a dobra, które do nich należą, należy klasztorom pozostawić. Zatem klasztory nie powinny stawać się nigdy domami prywatnymi. Kto zgodzi się, aby się takimi stały, będzie kanonicznie ukarany"; G. Dagron, Les moines, dz. cyt., s. 173n; tenże, Naissance d'une capitale, dz. cyt., s. 515-517; V. Desprez, Rozdziat VIII, Ruchy monastyczne i biskupi - doktorzy w Syrii i Azji Mniejszej, w: ŹM 22, 20.

${ }^{21}$ Por. Concilium Chalcedonense can. 2, CCO IX 1, 1, 70-71, ŹMT 24, 225-227: „Jeżeli biskup udziela święceń za pieniądze i czyni przedmiotem handlu laskę, której nie można sprzedawać, jeśli za pieniądze konsekruje biskupa, lub chorepiskopa lub prezbitera, diakona [...]. Kto był pośrednikiem w tym haniebnym i zakazanym handlu, [...] jeśli zaś jest $[. .$.$] mnichem, zostanie wyłączony ze$ wspólnoty”; tamże can. 3, CCO IX 1,1, 71-72, ŹMT 24, 227: „mnich nie powinien zajmować się sprawami niezwiązanymi z jego powołaniem. [...]. Obecny święty i wielki synod zarządził, by na przyszłość żaden [...] mnich nie dzierżawil majątków ani nie zajmował się interesami doczesnymi i nie przyjmował zarządu obcymi dobrami. Dopuszcza się wyjątek, gdy prawo zmusza do podjęcia się opieki nad maloletnim lub biskup miasta powierzy obowiązek troszczenia się o dobra kościelne albo każe, [...] zając się sierotami lub wdowami bez opieki [...]. Kto w przyszłości spróbuje przekroczyć te przepisy, będzie obłożony karami kościelnymi"; tamże can. 4, CCO IX 1, 1, 72-73, ŹMT 24, 229: „Słusznie zasługują na szacunek ci, którzy prawdziwie i szczerze podejmują życie zakonne. Niektórzy jednak życie zakonne traktują jako pretekst, aby czynić zamieszanie w sprawach Koscioła i państwa; wędrują z miasta do miasta i starają się o to, aby budować dla siebie klasztory. [...] ich obowiązkiem jest milować pokój i zajmować się jedynie postem i modlitwą oraz pozostawać w miejscu, które im wyznaczono. Nie wolno im wtrącać się w sprawy kościelne ani światowe ani się nimi zajmować oraz opuszczać swoich klasztorów, chyba, że w przypadku konieczności, nakaże im to biskup miasta. W klasztorach nie wolno przyjmować na mnicha niewolnika bez zgody jego włásciciela”; tamże can. 7, CCO IX 1, 1, 75, ŹMT 24, 231: „mnichom nie wolno wracać do świata. Zarządzamy, że ci, [...] zostali mnichami, nie powinni przyjmować służby wojskowej ani godności cywilnej. Należy wykluczyć tych, którzy odważyli się to uczynić i nie odpokutowali porzucenia wcześniej wybranego powołania dla Boga"; tamże can. 16, CCO IX 1, 1, 82, ŹMT 24, 241: „Dziewicom poświęconym Bogu nie wolno wychodzić za mąż. Dziewica, która poświęciła się Panu Bogu, tak samo i mnich, nie powinni wstępować w związki małżeńskie. Jeśli znajdą się tacy, którzy to uczynią, mają być wykluczeni ze wspólnoty. Postanawiamy jednakże, że lokalny biskup ma prawo okazać im miłosierdzie"; tamże can. 18, CCO IX 1, 1, 83-84, ŹMT 24, 243: „Przestępstwo sprzysięzenia się i spiskowania jest już zabronione przez prawo cywilne, przeto tym bardziej powinno być zakazane w Kościele Bożym. Jeżeli [...] mnisi związali się przysięgą i spiskują, [...] powinni zostać złożeni z urzędu"; tamże can. 23, CCO IX 1, 1, 87, ŹMT 24, 245 - 
powiązań mnichów z herezją w tym mieście jest osoba Eutychesa (ok. 370-455), archimandryty dużego i wpływowego klasztoru w Konstantynopolu. To wlaśnie głoszona przez niego błędna nauka o dwóch naturach Chrystusa przed wcieleniem, a jednej po wcieleniu, była powodem napisania Listu papicża Leona Wielkiego (440-460) do Flawiana (biskupa Konstantynopola w latach 443-449), w sprawie Eutychesa ${ }^{22}$, jak również główną przyczyną zwołania Soboru w Chalcedonie, na którym został on potępiony za wyżej wymienione poglądy ${ }^{23}$.

Wśród pierwszych klasztorów, jakie zostały zbudowane w Konstantynopolu, byl klasztor ufundowany przez prefekta Rufina ( $†$ 395), w którym zostal pochowany uczeń Pambo - Ammonios, przebywający czasowo w tym cesarskim mieście i tam nagle zmarły, o czym dowiadujemy się od historyka Palladiusza $^{24}$.

W Konstantynopolu znajdowały się również dziewice. Wśród nich na szczególną uwagę zasługuje św. Nikareta będąca po wieczystych ślubach dziewictwa i występująca wraz z innymi w obronie św. Jana Chryzostoma ${ }^{25} \mathrm{w}$ jego trudnym

247: „Należy wypędzić z Konstantynopola obcych duchownych i mnichów, którzy wywołują nieporządki. Doszło do wiadomości świętego synodu, że niektórzy duchowni i mnisi, bez polecenia swojego biskupa, a nawet wylączeni przez niego ze wspólnoty, przybyli do cesarskiego miasta Konstantynopola i przebywają tam dłuższy czas, czyniąc zamieszanie, wprowadzając nieład do spraw kościelnych i zajmując domy osób prywatnych. Z tego powodu obecny święty synod zarządzil, aby publiczny adwokat wielce świętego Kościoła Konstantynopola najpierw tych ludzi upomniał, aby opuścili cesarskie miasto. Jeśli zaś bezwstydnie pozostaną przy takim samym zachowaniu, wbrew swojej woli przez tego samego urzędnika zostaną wypędzeni $\mathrm{i}$ wysłani $\mathrm{z}$ powrotem do swoich miast”; tamże can. 27, CCO IX 1, 1, 90, ŹMT 24, 249: „ci, którzy porywają kobiety pod pretekstem ich poślubienia, oraz ci, którzy pomagają tym porywaczom i czyn ich aprobują, [...] jeśli są [...] mnichami, mają być wyłączeni ze spoleczności wiernych"; M. Starowieyski, Chalcedon (451), w: Sobory Kościoła niepodzielonego (część I: Dzieje), Tarnów 1994, 73-74.

22 Por. Epistula Papae Leonis ad Flavianum Constantinopolitanum (Tomus ad Flavianum), ACO II 2, 1, 24-25, tłum. T. Wnętrzak, ŹMT 24, 197-213.

${ }^{23}$ Por. Definitio fidei 10, ACO II 1, 2, 129, thum. T. Wnętrzak, ŹMT 24, 221-225.

24 Por. Palladius, Historia Lausiaca 11, 1 i 5, ed. Bartelink s. 50 i 54, ŹM 12, 99 i 101: „Uczeń ojca Pambo, Ammonios, [...]. Pewnego razu dla załatwienia jakichś spraw udal się do Konstanty. nopola i tam niebawem zmarł. Pochowano go w kaplicy zwanej Rufinowq. Powiadają, że jego grób uzdrawia cierpiących na febrę"; J. Pargoire, Rufinus, ByZ 8 (1899) 448.

${ }^{25}$ Por. Sozomenus, HE VIII 23, 1 i 3-6, GCS 50, 379-381, Kazikowski s. 566-568: „Wśód nich znalazła się Bitynka Nikareta, przedstawicielka znanego wśród mieszkańców Nikomedii rodu patrycjuszowskiego, którą otaczał nimb wieczystych ślubów dziewictwa i świętości życia. O ile wiem, była to najskromniejsza ze wszystkich poświęcających się Bogu niewiast, o jakich kiedykoiwiek słyszano. Umiała panować nad swym zachowaniem i nad mową, ułożyć sobie odpowiedni tryb życia i aż do śmierci swojej zawsze przenosiła rzeczy Boże ponad wazne sprawy życiowe. Dzielność i rozsądek pozwoliły jej stawić czoło nieoczekiwanym uderzeniom okrutnego losu, tak że się nawet nie oburzała, kiedy niesprawiedliwie pozbawiona została olbrzymiej fortuny po ojcu; i jeszcze z tych szczupłych zasobów, które jej pozostawiono, dzięki nieprzeciętnej umiejętności gospodarowania miała wraz z domownikami wszystko, co potrzebne do życia, i w dodatku innym również szczodrze służyła pomocą, chociaż młodość jej należala już do przeszlości. Jako milośniczka tego, co piękne 
polożeniu po synodzie Pod Dębem (403), na którym został on osądzony, a następnie zesłany na wygnanie, najpierw do Kukusos ${ }^{26}$, a później do Pityos w Armenii. Na nic się również zdały zabiegi dyplomatyczne papieża Innocentego I, zmierzające do uwolnienia Świętego ${ }^{27}$. Warto tu jeszcze dodać, iż przy omawianiu św. Nikarety, historyk Sozomen wspomina także o pannach żyjących w klauzurze kościelnej i mających specjalnie wydzielone dla nich pomieszczenie w świątyni, a których przełożoną nie zgodziła się jednak być owa Święta, mimo usilnych i wielokrotnie ponawianych próśb ze strony św. Jana Chryzostoma ${ }^{28}$. W liczbie kobiet wspierających duchowo i materialnie św. Jana Zlotoustego, była też diakonisa, Olimpiada, będąca wnuczką prefekta Ablabiosa i żoną Nebridiusza, który wkrótce po ślubie zmarl, zaś ona rozstała się z tym życiem jeszcze jako dziewica (zmarła po roku 407), według przekazu Palladiusza $^{29}$. O tej samej diakonisie pisał także Sozomen w swojej Historii $K o s_{c}{ }^{\prime}{ }^{30} a^{30}$. Do grona ówczesnych dziewic należały również trzy córki cesarza

i dobre, z życzliwości dla ludzi i z chęci przyjścia im z pomocą zajęła się ponadto przygotowywaniem różnych lekarstw na użytek chorych nędzarzy. Oczywiście w oparciu o te umiejętności pomagala niejednokrotnie wielu spośród swoich bliskich, którym na nic się zdała usługa zawodowych lekarzy. Bo za jakąś wprost Boską ingerencją wszystko, do czegokolwiek przyłożyła ręki, pomyślny osiągało rezultat".

${ }^{26}$ Por. Sozomenus, HE VIII 21-22, GCS 50, 377-378, Kazikowski s. 563-565.

27 Por. Sozomenus, HE VIII 28, 1-3, GCS 50, 388-389, Kazikowski s. 579-580.

28 Por. Sozomenus, HE VIII 23, 6-7, GCS 50, 380-381, Kazikowski s. 568: „I żeby rzecz ująć w skrócie, spośród żyjących w moich czasach niewiast poświęcających się Bogu nie znalem drugiej, która by się wzniosła aż na takie szczyty moralnej siły, dostojeństwa i wszelkich innych wartości. Ale chociaż była tak wspaniałą kobietą, ogół o niej nic nie wiedział. Albowiem w swej skromności i upodobaniu do chrześcijańskiej mądrości życia zawsze pragnęla pozostawać w ukryciu, i to tak dalece, że nawet nie starała się dostąpić godności diakonisy, ani té்-pomimo wielokrotnych zachęt ze strony Jana - nigdy nie zgodzila się zostać przełożoną panien żyjących w klauzurze kościelnej”.

${ }^{29}$ Por. Palladius, Historia Lausiaca 56, 1-2, ed. Bartelink s. 252, ŹM 12, 211-212: „Gorliwość Melanii naśladowała i za jej przykładem szła wielce czcigodna i niestrudzona Olimpiada. Była córką komesa Seleukosa, wnuczką prefekta Ablabiosa i przez kilka dni małżonką Nebridiusza, jednego z naczelników miasta; nigdy jednak nie należała do nikogo. Mówiono o niej, że umarła jako dziewica, oblubienica Slowa prawdy. Cały swój majątek rozdała ubogim. Toczyła zacięty bój za prawdę, wiele niewiast pouczyła o wierze, okazywala szacunek kapłanom, obdarzała czcią biskupów, tak że zaliczono ją do grona wyznawców. Za jej sposób życia mieszkańcy Konstantynopola włączyli ją do grona wyznawców, gdyż umarła i odeszła do Pana tocząc walkę wedle Bożej woli”.

${ }^{30}$ Por. Sozomenus, HE VIII 24, 4 i 6-7, GCS 50, 382, Kazikowski s. 570-571: „W tej krytycznej sytuacji bohaterką okazała się również diakonisa Olimpia. Skoro bowiem z wymienionego tu powodu przyprowadzona została do sądu, na zapytanie prefekta, czemuź to podpaliła kościól, odpowiedziala: «Tego rodzaju poczynania nie wchodzą w rachubę na obranej przeze mnie drodze życia; bo cały swój majątek - a było tego niemało! - poświęciłam na odnowienie Bożych przybytków». [...]. Ale chociaż wszystkie inne niewiasty pod wpływem lęku ustąpiły wobec podobnych nalegań prefekta, Olimpia odrzekła: «Nie jest to w myśl prawa, by kobieta pojmana w tłumie na skutek oszczerstwa, a w sądzie nie przekonana co do słuszności żadnego z punktów oskarżyciela, zmuszona była $z$ kolei do obrony zarzutow, $z$ jakich nikt oczyszczać się nie musi». [...]. Nazajutrz 
Arkadiusza († 408): Pulcheria (399 - ok. 453), Arkadia i Marina, prowadzące ascetyczny tryb życia, przy czym najbardziej aktywną spośród nich okazała się Pulcheria, która stała się fundatorką nowych klasztorów, a także miała znaczny wpływ na wychowanie swojego młodszego brata, późniejszego cesarza Wschodu, Teodozjusza II (sprawował on władzę w latach 408-450), wychowując go m.in. w duchu pobożności oraz szacunku do osób duchownych i mnichów ${ }^{31}$.

jednakże stawiwszy się przed sądem, wymierzył jej wysoką grzywnę w złocie; myślał bowiem, że w ten sposób zmusi ją do zmiany zdania. Ona jednakże na pieniądze nie zwracała uwagi, toteż bynajmniej nie ustąpiła; i wreszcie opuściwszy Konstantynopol, zamieszkała na stałe w Kyzikos"; tamże VII 27, 8-9, GCS 50, 388, Kazikowski s. 579: „Jan tymczasem nawet na wygnaniu rósł w sławę. Pieniędzy bowiem mając pod dostatkiem - jako że niezależnie od wielu innych, którzy je dowieźli, wysłała je również i diakonisa Olimpia - wykupił od Izauryjczyków wielu jeńców i odprawił ich w ojczyste strony. Wielu potrzebującym użyczył niezbędnego wsparcia, a tych, którzy pieniędzy nie potrzebowali, zdobył sobie słowem. I miłowali go niezmiernie mieszkańcy Armenii, wśród których przebywał, oraz ludność obszarów sąsiednich. Odwiedzalo go zaś tak bardzo wielu, tak z Antiochii, jak i z pozostałych okolic Syrii i Cylicji”.

31 Por. Sozomenus, HE IX 1, 1-5, 7-8 i 10, GCS 50, 390-391, Kazikowski s. 581-583: „Taki zatem przebieg miały wydarzenia związane $\mathrm{z}$ osobą Jana. Niedługo zaś po jego śmierci, w trzecim już roku sprawowania funkcji biskupa Konstantynopola przez Attyka, za konsulatu Bassusa i Filipa, rozstał się z życiem Arkadiusz, jako następcę na cesarskim tronie pozostawiwszy swego syna, Teodozjusza, dziecię, które od niedawna dopiero przestano karmić mlekiem. Zostawil tei córki po sobie, Pulcherię, Arkadię i Marinę, młodziutkie jeszcze dziewczęta. [...]. Oto bowiem strzegąca wszechrzeczy moc Boża, z góry przewidując największą pobożność cesarza, opiekunką jego osoby i władztwa ustanowiła siostrę jego, Pulcherię. Ta zaś lat piętnastu jeszcze nie mając, otrzymala dar rozumu ponad wiek i mądrości natchnionej od Boga. I najpierw poświęciła Bogu swe panieństwo i wdrożyla siostry do takiego samego sposobu życia, po to, żeby do pałacu nie wprowadzać innego mężczyzny i zniszczyć w zarodku możliwość zazdrości i zasadzki. A chcąc dodatkowo jeszcze potwierdzić raz podjęte decyzje i na świadectwo swoich postanowień powolać Boga samego, kapłanów i ogół poddanych, ofiarowała i złożyła w kościele konstantynopolskim arcydzieło ze złota i drogocennych kamieni, rzecz najpiękniejszą ze wszystkich, jakie kiedykolwiek podziwiano: stół święty, dar wotywny w intencji wlasnego jej panieństwa i cesarskich rządów brata. Jednocześnie intencję tę kazała wypisać na samym brzegu stołu, tak żeby każdy mógl bez trudu zauważyć napis. [...]. Umiała bowiem przemawiać i pisać poprawnie po łacinie i po grecku. [...]. Siostra tymczasem udzielala mu wskazówek, jak ma występować publicznie, jak ma zachować stateczność i cesarski majestat; od niej się uczył, jak ma nosić odzież, w jaki sposób ma siedzieć i chodzić, [...]. Naprowadzala go zwłaszcza na drogę pobożności, przyzwyczajała do ciagłej modlitwy i odwiedzania kościołów; [...] ponadto szanować kapłanów i innych zacnych ludzi, a także tych, którzy uprawiają mądrość według chrześcijańskich zasad życia. [...] zbyt wiele czasu by zajęło wyliczanie, gdzie i ile wzniosła kościołów, hojnie je wyposażając; ile wybudowała przytułków dla biednych $\mathrm{i}$ pielgrzymów, ile klasztorów, nieustannie tożąc na nie pieniądze oraz zapewniając wyżywienie ich mieszkańcom”; tamże IX 3, 1-2, GCS 50, 394-395, Kazikowski s. 587-588: „Ale, jak mówią, Bóg niejednokrotnie i we wszystkich innych sprawach obwieszczal Auguście to, co dopiero ma nastąpić, a ponadto wiele wydarzeń świadczy o szczególnej Jego łaskawości tak dla niej, jak i dla jej sióstr: albowiem i one stosują ten sam sposób postępowania, troszcząc się o kapłanów i świątynie i współzawodnicząc w szczodrości na rzecz potrzebujących wsparcia pielgrzymów i biednych, przeważnie jednakowo się wszystkie odżywiaja i jednakowo występuja publicznie; wspólnie też w nocy i we dnie uwielbiają Boga i zgodnie ze zwyczajem zacnych niewiast troszczą się pilnie o tkanie odzieży i o inne tego rodzaju zajęcia. Chociaż bowiem były córkami 
Na zakończenie naszych rozważań o życiu monastycznym w Konstantynopolu, warto jeszcze przypomnieć, że pod koniec IV wicku przebywała w nim Egeria $^{32}$, Ewagriusz z Pontu (345-399) ${ }^{33}$, Melania Młodsza $(† 439)^{34}$, jak również Jan Kasjan (ok. 360-435), który wraz zc swoim przyjacielem Germanusem przybyli tam ok. 400 r. i z rąk Jana Chryzostoma przyjęli święcenia (Kasjan diakonat, zaś Germanus kapłaństwo), a następnie (ok. 404) udali się do Rzymu ze specjalnym posłaniem Chryzostoma, adresowanym do Innocentego I (401417), o czym dowiadujemy się z drugiego listu tegoż papieża skicrowanego do duchowieństwa Konstantynopola w obronic Jana ${ }^{35}$.

\title{
LA VITA MONASTICA A COSTANTINOPOLI PRESSO GLI AUTORI DEL IV E V SECOLO
}

\author{
(Riassunto)
}

Dall'analisi che abbiamo presentato sopra, relativa alle fonti patristiche del IV e del V secolo sul tema "Il monachesimo a Costantinopoli", si possono trarre le seguenti considerazioni. Già l'imperatore Costantino il Grande prestò interesse a questa forma di vita. Ciò è testimoniato dalla lettera, non conservatasi, indirizzata dall'imperatore stesso a sant'Antonio del deserto. Oltre a questo, anche sant'Antonio il Grande scrisse al sovrano in difesa di sant'Atanasio il Grande. Nell'anno 320,

władcy i w pałacu cesarskim urodziły się i wzrastały, bezczynnośé i lenistwo uznały za rzecz niegodną obranego przez siebie stanu: panieństwa poświęconego Bogu na służbę; toteż wykluczyly te przywary ze swojego życia".

32 Por. Egeria, Itinerarium 23, 8-9, SCh 296, 230-232, OŻ 13, 184: „Następnego dnia, przeprawiwszy się przez morze, przybyłam do Konstantynopola, [...]. Gdy tam przybyłam, odwiedziłam poszczególne kościoly i sanktuaria Apostołów, a także martyria, które są tu bardzo liczne".

${ }^{33}$ Por. Palladius, Historia Lausiaca 38, 1-2 i 6, ed. Bartelink s. 192-196, ŹM 12, 177-178 i 179: "Nie wypada mi pominąć historii Ewagriusza, słynnego diakona, [...] żył zgodnie ze swymi zasadami, a po ascetycznym życiu na pustyni umarł godnie, mając pięćdziesiąt cztery lata, [...]. Pochodził z Pontu, [...]. Po śmierci św. Bazylego, biskup Grzegorz z Nazjanzu, [...], zwrócił uwagę na zdolności Ewagriusza i wyświęcil go na diakona. Potem, na wielkim synodzie w Konstantynopolu przekazal go blogosławionemu biskupowi Nektariuszowi [...]. Tam, w wielkim mieście zabłysnął wymową [...]. Na to Ewagriusz: «Jeżeli Bóg wyrwie mnie z tego nieszczęścia, a ujrzysz mnie jeszcze w Konstantynopolu, to możesz myśleć, że zasługuję na tę karę»”.

${ }^{34}$ Por. Vita Melaniae 4, 53-56, SCh 90, 230-238.

${ }^{35}$ Por. Palladius, Dialogus III 80, SCh 341, 76; Innocentius I, Epistula 7 (ad clerum et popul. Constantinop.), PL 20,50IB; Ioannes Cassianus, De incarnatione Domini contra Nestorium VII 31 , 1 i 6, CSEL 17, 389-391; Sozomenus, HE VIII 26, 1-2 i 7-8, GCS 50, 384-385, Kazikowski s. 574-575; Gennadius Massiliensis, De viris illustribus 61, PL 58, 1094A-1095A, thum. SWP 224: „Kasjan, z pochodzenia Scyta, wyświęcony diakonem w Konstantynopolu przez bpa Jana Wielkiego [Chryzostoma, 400 r.]". 
Costantino riconobbe i privilegi delle persone di ambo i sessi che sceglievano di vivere nella verginità. Alla famiglia dell'imperatore fu legata la vita di Arsenio, il quale educò i figli di Teodoro il Grande e, dopo essersi convertito, si dedicò alla vita eremitica nel deserto, in Egitto. I monaci egiziani erano soliti recarsi dall'imperatore di Costantinopoli, per esempio, con la richiesta di essere dispensati dal versamento dei tributi. Le informazioni da noi raccolte e sopra riportate sono testimonianza della presenza di legami tra Costantinopoli e i monaci d'Egitto, nonché delle influenze di questi ultimi sulla vita della capitale dell'impero. Occorre aggiungere che al palazzo imperiale fu legata la figura di Marciano di Cira, il quale rinunciò alla carriera a corte e, sotto il regno di Valente, visse da eremita nel deserto della Siria. Dopo la morte dell'imperatore, si dedicò alla vita monastica, non lontano da Antiochia, anche un certo Zenone, attivo nei servizi speciali ,agentes in rebus” come spia della polizia.

I primi monasteri maschili e femminili di Costantinopoli furono costruiti per opera del vescovo Macedonus e del diacono Maratone, entrambi semiariani. Contro di loro si schierò il Concilio di Calcedonia, il quale promulgò un canone avente lo scopo di sottomettere i monaci alla giurisdizione dei vescovi. Un ulteriore elemento di analisi è quello relativo ai legami tra il monaco Eutiche e le pratiche eretiche. Contro il suo insegnamento intervenne papa Leone con la lettera a Flaviano, vescovo di Costantinopoli. Inoltre, la dottrina di Eutiche fu condannata anche dal Concilio di Calcedonia. Qui vivevano ancora monaci legati all'eresia macedonese.

A Costantinopoli si trovavano anche delle vergini. Fra loro vi erano: la diaconessa Olimpia, le figlie dell'imperatore Arcadio (Pulcheria, Arcadia e Marina). Nella città vissero temporaneamente Egeria, Evagrio Pontico, Melania la Giovane e san Giovanni Cassiano. 